\title{
CHURCH POSSESIONS - A TEMPTATION OF MODERN TIMES
}

Nicolae-Coriolan Dura*

\section{Introduction}

The times the Romanian society is going through are, both for the Orthodox Church and for its representatives, a period of searching for their own identity; the so-called civil society, which desires to hold an independent, neutral position from a religions point of view, is requesting an answer from the Church regarding the Church's right to own and administrate material possessions. More and more voices are heard asking this question, in a context of a period characterized by the outburst of information through massmedia channels. The high rate at which the Orthodox Church is targeted should, at least, alarm us, as the greatest part of those who raise such questions finally prove not to be really interested in the answer or in the issue itself. The fact that the problem is falsely dealt with in the society can be proved by the attack being directed against the Romanian Orthodox Church exclusively. The question which is conveyed to the society does not refer to a general problem, namely the possessions of the religious cults, but only to the possessions of a certain cult, namely the Romanian Orthodox Church.

The issue can be dealt with from two perspectives. Firstly, we are concerned about the fact that the problem is falsely put forward in the public space; however, there are also some beneficial aspects, since, by seriously treating the issue, the Romanian society

\footnotetext{
* PhD, Lecturer at the Faculty of the Orthodox Theology "1 Decembrie 1918" University, Alba Iulia.
} 
is able to solve a problem that should lie at the foundation of a sound society for a long time, an issue solved by other European societies, whose institutions, by knowing one another, have come to respect and support one another.

Unfortunately, or fortunately, the Romanian society needs, first of all, to grow up, and then to seriously deal with all the issues it is facing, and afterwards, to involve specialists in solving the issues, experts who, by their authorized opinion, should settle these issues.

Given the fact that the Orthodox Church is a human-divine institution with a bi-millenary historical course, it has undergone the impact of time. It came to life out of godly love at the boundary between the old man and the new one. It was subjected to Judaic and pagan persecutions, and it got through victoriously every time, due to the fact that it is the religion of man for his fellow man and for the kingdom of heaven, and not of a man for a certain civil state, an ephemeral lust for human ideology. Empires have succeeded one another, kingdoms had their periods of arising, development, and fall, like their founders. But the Church has survived, thanks to the sacrifice of its Founder and according to His teaching "... and the gates of hell will not overcome it" (Matth. 16.19).

Church possessions have always represented a temptation, beginning with the Roman emperors, until the period of communist ideology, and even nowadays. The temptation is not a new thing, it has its origin in remote times. Its roots can be identified in Biblical times. At first sight, we are tempted to believe that its source could be materialized in a historical character. Cain had this feeling towards the possession of his brother Abel, that is the godly love, but the real source is represented by our forefathers, Adam and Eve. They were tempted by the possession God holds, and through the ancient sin they wanted to hold on to this possession, which in fact they did not deserve. They wanted to be gods, but without God. Their desire was to be good, while being evil. That's why our Savior Jesus Christ asked the following question: "Why do you ask me about what is good? There is only One God who is good" (Matth. 19.17). 
The present study is meant to be an answer to several questions from a certain part of the civil society:

- How has the Church come to possess goods? with them?

- To whom are they destined, or what does the Church do

- Are these persons authorized to administrate them? And if so, who are they, and what is their mandate, more precisely, what is the framework of the Church possessions inside the Church and in the society implicitly?

How has the Church come to possess goods?

The Holy Scriptures, by presenting the history of the redemption of humankind, mirrors the fact that man, even from the moment of his creation, receives, as purpose of his existence, the commandement to "fill the earth and subdue it" (Gen. 1.28). The earth, which was beautified by God and brought to the stage of being "very good" (Gen. 1.31). In this evolutive period of the whole creation, God created man in his own image and likeness (Gen. 1.2627). As a result of the original sin, the whole created nature, given into man's care, was affected by the shadow of sin, thus being misled from the purpose it was created for. God's image and likeness was altered, man came under the shadow of death, however, without totally breaking the connection with his Creator, and without losing the purpose for which he was created.

The biblical history of the Old Testament is eloquent with respect to the above mentioned facts; people increased in number on the earth, and came into the possession of land to toil on and, if need be, to protect it and to enjoy its crops. Thus, two different feelings emerged bearing the same name: "mine" as possession/ property, and "mine" - referring to the fact that I only have a right as administrator, the possession belonging to our Creator (1 Cor. 4.7). The most consistent example is to be found in the Book of Job, synthetized in the well-known expression: "The Lord gave and the Lord has taken away; may the name of the Lord be praised" (Job 1.21). The material possessions represent for the chosen man of this 
period not a purpose in itself, but just the means to come to the purpose itself, which is coming to know God.

The period of our Savior Jesus Christ is characterized by the same mentality. Our Savior urges on those who believe in His teaching to "seek first God's kingdom and His righteousness, and all these things will be given to you as well" (Matth. 6.33). Even the Holy Apostles were confronted by the same dilemma, the verdict given by our Savior concerning the rich young man being: "I tell you the truth, it is hard for a rich man to enter the kingdom of heaven" (Matth. 19.23). This statement made the Apostles meditate. The holy Apostle Peter was the one to ask our Lord: "We have left everything to follow you! What then will there be for us?" (Matth. 19.27). Ordinary people or highly educated ones are summoned to give a personal answer to this desideratum: "mine". Our Savior teaches them how to pray, giving them a concrete example: the possessions of the Apostles, of our Savior, of the disciples and of the holy women, belong to them all. We have concrete examples: Judas Iscariot, the case of Zebedee's two sonsand the favor that their mother requests for them from the Teacher, and the Apostles reaction in this context, let alone the dilemma of the Holy Apostle Peter: "Who then can be saved?" (Matth. 19.25) or his soul drama on the night of his disowning the Lord, when he does not understand anything of what has remained of the new kingdom, a drama which we will find in the circle of the Apostles, too ${ }^{1}$ ).

The Sacrifice of our Savior on the Cross, His Ressurection, completed by the descent of the Holy Ghost at the Pentecost, were needed so that the Apostles could open their eyes and their minds to understand the role of material possessions in the life of Christians, and of the Christian Church, too. Saul of Tars will come to know the society in which "there were no needy persons among them. For those who owned lands or houses sold them, brought the money from

\footnotetext{
${ }^{1}$ See the dialogue between Luke and Cleopas on their way to Emmaus: "but we had hoped that he was the one who was going to redeem Israel. And what is more, it is the third day since all this took place" (Luke 24.21).
} 
the sales, put it at the apostles feet, and it was distributed to anyone as he had need." (Acts 4. 34-35). It was also Paul who, after repenting, will synthetize this feeling, admitting that they "were aliens and strangers on earth" (Hebr. 11.13).

The jurisprudence of those times demonstrates the fact that, if there were big question marks over the common possessions (of the Church) from the outside, the perception from the inside was not clear either. No matter if those possessions were many or few, they represented a permanent temptation, or a reason for dispute (sometimes groundless at first, but proved to be true later on). An illustration of it is the case of Ananias and Sapphira (Acts 5.1-11), or the reason for choosing the seven deacons (Acts 6.1-6), adding the example of the Church of Samaria to which Simon the Sorcerer belonged, too. Even the Holy Apostle Paul was to be accused of taking possession of the collection for the poor in Jerusalem.

From the above mentioned facts we can see that the Church came to own possessions which were especially entrusted to her. The persons who were entitled to have this responsibility were the Apostles, the destination for which these possessions were entrusted to them was well established, and the manner in which they were to be administrated was consolidated. Obeying the command of our Saviour Jesus Christ: "Love each other as I have loved you" (John 15.12), the Christians give up the mentality of "mine," replacing it by that of : "We offer You these gifts from Your gifts, in all and for all".

From the point of view of the Roman state, the Church is not yet under the incidence of legality. Being regarded as a Judaic sect, organized on the principles of a family, the belongings they have to administrate are minor. "From the times of the emperor Nero, during the persecutions, Christianity had been considered odium generis humani, for which reason they could not be accepted in the empire, being considered dangerous for the Roman institutions and the safety of the empire. The juridical status of Christians remained the same 
until the legal acknowledgement of the Church. They were considered outlaws: christiam non sint" ${ }^{2}$ ).

However, whom are the possessions for? According to the Apostolic traditions already mentioned, the fundamental Church legislation preserves its memory in a norm, at high esteem being considered the poor ${ }^{3}$, the bishop and the subordinate clerics. We state the above, as the Apostolic Canon 41 decides that the goods shall be granted to "those in need through the presbyters and deacons with fear of God and all reverence, while he himself may partake thereof whatever he needs (if he needs anything) for his necessary wants, and for brethren who are his guests, so as not to deprive them of anything, in any manner; for God's law has enjoined that those who serve at the altar are to be maintained at the altar's expense. The more so in view of the fact that not even a soldier ever bears arms against belligerents at his own expense" $(1$ Cor. 9.7-13) .

The Canon is not a single one, for in 341 in Ancira, the Holy Fathers participating in the synod decided the following: "The bishop shall hold possession over all things of the Church in order to administer them for all those in need, with reverence and fear of God, while he himself may partake thereof whatever he needs (if he needs anything) for his necessary wants, and the brethren who are his guests, so as not to deprive them of anything, according to the godly Apostle, who says: But if we have food and clothing, we will be content with that" (I Timothy 6,8$)^{5}$.

In order that things should be clearly stated, and the Christian communities be enlightened regarding the destination of the goods

\footnotetext{
${ }^{2}$ Iorgu D. Ivan, Bunurile bisericeşti în primele şase secole, Bucureşti, Basilica Publishing House, pp. 48-49.

${ }^{3}$ Canon 12 of the local synod held in Sardica: Nicodim Milaş, Canoanele Bisericii Ortodoxe, inso ite de comentarii, vol. II, part. I, with commentaries, translated by Uşor Kovincici şi Nicolae-Popovici, Arad, 1934, p. 139

${ }^{4}$ Canon 41, apostolic: Nicodim Milaş, Canoanele Bisericii Ortodoxe ..., vol. I, part. I, Arad, 1930, p. 250.

5 Canon 25, local synod in Antioch: Nicodim Milaş, Canoanele Bisericii Ortodoxe ..., vol. II, part. I, p. 80.
} 
entrusted to the Church, in 343 the Holy Fathers of the synod in Sardica granted the word uttered by Bishop Osiu the value of a legal regulation, deciding that: "...For many of the Bishops keep visiting the camp, and this is especially true of the Africans, who, as we have learnt from our dear brother and fellow Bishop Grains, will not accept saving advice, but scorn in such fashion, that one man keeps carrying a great many various petitions to the camp, not withstanding that they cannot be of any benefit to the Church, and not, as ought to be done, and as also befits the situation in regard to poor persons and layman or to widows, by way of gaining assistance and succor, but with a view to obtaining wordly offices and favours for certain persons. This baseness, therefore, causes us no little dissatisfaction, but scandal and contrition. We have deemed it more proper and becoming for a Bishop to lend aid of his own whenever anyone is being forcibly ill-treated, or any of the widows is being wronged, or against any orphan is being deprived of what belongs to him, and in whatever other situations demand such attention [...]. So if you consent to this, you all give your votes for it". They all responded: "this should be decided".

Another important category regarding the destination of these goods are the Church priests, and especially the poor priests ${ }^{7}$ as, by emerging the churches of village parishes, they could not maintain a frame of economic development similar to that of the churches in more important cities ${ }^{8}$.

The loyalty to the tradition of the primary church has been preserved to the present day inside the Romanian Orthodox Laws, for the canons mentioned above were applied on the Romanian

${ }^{6}$ Canon 7, local synod VI, Sardica: Nicodim Milaş, Canoanele Bisericii Ortodoxe ..., vol. II, part. I, p. 132.

${ }^{7}$ Canon 58, apostolic: "The Bishop or presbyter who will not look after the clergy or the people, not teaching them the rightful faith, shall be put under the ban of the church; and if they persist in negligence and idleness, he shall be anathemized as being an offender of his brother". Nicodim Milaş, Canoanele Bisericii Ortodoxe ..., vol. I, part. I, p. 274.

${ }^{8}$ Michael Kaplan, Bizan , Bucureşti, Nemira Publishing, p. 240. 
territories both in the past - here we should only mention the complex collection of the nomocanons "Îndreptarea legii", which contains as chapter 41 exactly the Apostolic canon $41^{9}$, and as chapter 25 the contents of the local canon of Antioch ${ }^{10}$, - and at present. Eloquent remains the article 17 of the Regulations for the administration of Church possessions: "the Diocesan Bishop has the following duties:

- He guides and controls, through the Diocesan Vicar, through representatives and through the Inspection Body, the manner in which the archdiocesan properties are administrated, as well as of the lower parts of the Diocese;

- He approves, directly or through the Diocesan Vicar, the administration papers drawn up by the Diocesan Council, the Permanent Body of the Diocesan Council, or by the Office of Diocesan Administration, regarding the diocesan properties or those of the subordinate units" 11 .

Are any persons authorized to administrate these possessions? And if so, who are they, and what is their mandate?

By the apostolic tradition we can notice that this quality and obligation of administrating the Church possessions was firstly granted and acknowledged to the Apostles, and then to the bishops they established in the communities founded by them ${ }^{12}$.

9 Îndreptarea legii 1652, Bucureşti, Romanian Academy Publishing, 1962, p. 393.

${ }^{10}$ Indreptarea legii 1652, ... pp. 424.

${ }^{11}$ Regulametul pentru administrarea averilor bisericeşti 1950, Bucureşti, Ed. Institutului Biblic şi de Misiune Ortodoxă, 1953, p. 350.

12 Canon 41, Apostolic: "We ordain that the Bishop have authority over the goods of the Church, for if he is to be entrusted with the precious souls of men, the more are temporal possessions to be entrusted to him. He is therefore to administer them all of his own authority..." Nicodim Milaş, Canoanele Bisericii Ortodoxe ..., vol. I, part. I, p. 250; as well as canon 24, local synod of Antioch: "The rules and regulations of the Church must be rightly kept for the Church with all diligence and in all good conscience and faith reposed in God, who is the superintendent and judge of all things, and the judgement and authority of the Bishop entrusted with all the laity and souls of all the members 
Together with the development and spreading of Christianity, the administration of Church possessions in a diocese by only one person becomes impossible. That is why a special attention given to the canons indicates the fact that, in order to avoid any suspicion regarding the administration of these possessions, the regulations according to which the goods are to be administrated will be studied thoroughly. The canonical jurisprudence reveals the fact that the bishop remains the main administrator with power of resolution, but in the administration of the goods all the priests or clerics of the diocese that the bishop leads are also included. While the regulation of the Apostolic Canon 39 imposed the clergy "not to do anything without the Bishop's approval"13, the same local synod held in Antioch in 341, in canon 24, stipulates: "What belongs to the dominion of the Church is manifest and well-known to the Presbyters and Deacons under his jurisdiction, so that these persons ought to be well-aware and not ignorant of whatever is property of the church, so

of the congregation gathered in church. What belongs to the dominion of the church is manifest and well-known to the presbyters, and deacons under ought to be well aware and not ignorant of whatever is property of the church, so that nothing should escape their observation to enable them, in case the Bishop should exchange life, in view of the fact that the things belonging to the dominion of the church are manifest to prevent any of them from being lost, and to see that none of the Bishop 's own things are disturbed on the pretense that they are ecclesiastical property. It is just and pleasing to both God and man that the bishop should leave his own property to whomsoever he may will it, but that things belonging to the church should be kept for it; and that neither should the church sustain any loss or damage, nor should property of the Bishop be confiscated on the pretence that it belongs to the church; nor should these persons be involved in any trouble in claims thereto, with the result of defaming him after death". Nicodim Milaş, Canoanele Bisericii Ortodoxe ..., vol. II, part. I, p. 79.

13 "Let not the presbyters or deacons do anything without the sanction of the Bishop, for it is he who is entrusted with the people of the Lord, and of whom will require the account of their souls".- canon 39, Apostolic, Nicodim Milaş, Canoanele Bisericii Ortodoxe ..., vol. I, part. I, p. 247. 
that nothing should escape their observation"14 for these ones ought to know the destination of the goods of the church they belong to. And this for three reasons. Firstly, for they had the right and obligation to know which are the goods of the church, as well as the manner of their administration, secondly they had the right and obligation to know which are the goods of the church and which are the Bishop's own goods ${ }^{15}$, and thirdly: in case the Bishop died and the parish became vacant, they should know how to administrate the goods until the arrival of the new Bishop ${ }^{16}$.

At the same time we can notice the appearing of a new aspect of the issue of Church possessions, which during the Apostolic period was not thoroughly clarified, namely the goods belonging to the Bishop. The canonical jurisprudence indicates the fact that the bishops, being married and having their own families, possessed their own goods. The year 343 bears witness to this fact, as the canon 12 of the local synod VI held in Sardica disposed: "in such cases, we judge it to be allowable, [to the bishop] when it comes to their going to their own possessions and gathering in the crops thereof, for them to stay for three consequtive Sundays, that is, for in this manner no damage or loss or injury in spite of his absence ..."17. The obligatory character of the decisions of the kind, as we can see that in 419 the issue was brought up for discussion again on the occasion of another local synod, namely the local synod held in Carthage, where they disposed that: "Moreover, it seemed good that no one should be

${ }^{14}$ Canon 24, local synod IV, Antioch, Nicodim Milaş, Canoanele Bisericii Ortodoxe ..., vol. II, part. I, p. 79.

15 "... and none of the Bishop 's own things are disturbed on the pretense that they are ecclesiastical property ...”, canon 24, local synod IV, Antioch, Nicodim Milaş, Canoanele Bisericii Ortodoxe ..., vol. II, part. I, p. 79.

16 "... that, if happens to the Bishop to pass away, what belongs to the Church should be well known to prevent anything from being lost ...”, canon 24 local synod IV, Antioch, Nicodim Milaş, Canoanele Bisericii Ortodoxe ..., vol. II, part. I, p. 79.

${ }^{17}$ Canon 12 of the local synod VI, Sardica, local synod IV, Antioch, Nicodim Milaş, Canoanele Bisericii Ortodoxe ..., vol. II, part. I, p. 139. 
allowed to leave his chief cathedral and go to another church built in the diocese, or to neglect the care and frequent attendance upon his own cathedral by reason of too great care of his own affairs" $"$. Even over this matter the Church did not allow the existence of any suspicion. For "Item, it was ordained that, if any bishop should prefer to his Church stranger to blood, relationship with him, or his heretical relatives, or pagans, as his heirs, he shall be anathematized even after his death and his name shall by no means be recited among those of the priests of God, nor can he be excused if he died intestate, because being a bishop he was bound not to postpone making such a disposition of his goods as was befitting his profession"19.

The administrative practice, as well as the variety of the manners of administrating the goods, imposed on the Church a strict economic administrative organization. Thus, there appeared the necessity that a person should be appointed, who had the duty to administrate the Church goods under the careful supervision of the bishop, and who had to account before the bishop and the diocesan priests. This was the Steward. He already existed in the early life of the Church, even if the necessity of such an office, of a Church official $^{20}$, was hastily mentioned, sometime between 385 and 412, when in the canon 10, Theophilus, the Patriarch of Alexandria, stated: "Thus, by the decision of the whole priesthood, a new treasurer shall be sat in, for whom also the Bishop Apollo should consent to let him spend the Church money profitably"21. The necessity of this office was pertinent, as in 451 this subject was being debated in Chalcedon. The decision of the Holy Fathers at the ecumenical synod IV, in Chalcedon, becomes a norm in time: "Since

${ }^{18}$ Canon 71 of the local synod, Carthage, local synod IV, Antioch, Nicodim Milaş, Canoanele Bisericii Ortodoxe ..., vol. II, part. I, p. 234.

${ }^{19}$ Canon 81 of the synod VIII, Carthage, Nicodim Milaş, Canoanele Bisericii Ortodoxe ..., vol. II, part. I, p. 243.

${ }^{20}$ Nicodim Milaş, Canoanele Bisericii Ortodoxe ..., vol. I, part. II, p. 328.

${ }^{21}$ Canon 10, Theophilus of Alexandria, Nicodim Milaş, Canoanele Bisericii Ortodoxe, inso ite de comentarii, vol. II, part. II, Arad, 1936, p. 181. 
in some churches, as we have been informed, the Bishops are administering the ecclesiastical affairs with the services of a Steward, it has seemed most reasonable and right that each and every church, that has a Bishop, should also have a Steward selected from its own Clergy to manage the ecclesiastical affairs of that particular church in accordance with the views and ideas of its own Bishop, so as to provide against the administration of the Church being unwitnessed, so as to prevent the property of the same church from being waisted as a result of such stewardless administration and to present any obliquy from attaching itself to holy orders" ${ }^{22}$. An attentive look at canon 2 of the ecumenical synod IV signals us the fact that the appointment of a steward with a malicious intention becomes nonexisting and is drastically punished with the anathema" ${ }^{23}$.

The canonical jurisprudence show us that the subject was taken again, this time in the year 787 on the occasion of the ecumenical synod VII, which wanted to firmly impose the principle of the clear administration of the Church goods. Thus the decision of the synod imperatively disposes: "All of us being obliged to keep the divine canons, we ought to maintain by all means inviolable the one saying that there should be stewards in every church. Accordingly, if each Metropolitan appoints a Steward in his church, it is well and good; but if not, the Bishop of Constantinople is given permission to appoint a Steward in the same church ex officio. Like permission is given also to Metropolitans, if the Bishops under them do not care to appoint stewards in their own churches. The same rule is also to be observed in the case of monasteries" 24 .

The canonical norms indicate the fact that both the Bishop and the priest or the head of the monastery together with the Steward

${ }^{22}$ Canon 26 ecumenical synod IV; R.C. Dron, Canoanele, Text şi interpretare, Sinoadele ecumenice, vol. II, Bucucreşti, Tipografia căr ilor bisericeşti, 1935, p. 205.

${ }^{23}$ Canon 2, ecumenical synod IV, Nicodim Milaş, Canoanele Bisericii Ortodoxe ..., vol. I, part. II, p. 188.

${ }^{24}$ Canon 11, ecumenical synod VII, Nicodim Milaş, Canoanele Bisericii Ortodoxe ..., vol. I, part. II, p. 511. 
were obliged to keep the inventory of the church goods. Thus all the goods are recorded in a special register, drawn up by the Steward, certificated by the Bishop, and kept in the archives of the respective diocese. The local synod VIII held in Carthage, decides that: "presbyters should not sell the goods of the Church in which they are allowed to sell land possessed by the church without the knowledge of the synod or of their presbyters. So, if there be no need, the bishop shall not be forgiven in case he abuse the properties recorded in the Church register" 25 .

\section{Conclusions}

For an outsider, no matter if he may be a novice, a secular, an atheist, a Christian of the Church, a citizen of the European Union, or a person of any other quality, the type of organization and the structure according to which the Romanian Orthodox Church guides itself may seem stuck in time. Expression like: "the canons are oldfashioned", or "The Church must keep pace with the times they live in", and others of the kind, have no echo inside the Church. The fact that the page on which they were written have turned yellow bearing the mark of time, implies realizing the importance of preserving a priceless treasure handed over by the wise of the times passed; as well, the fact that they have been preserved as manuscripts, and not as as famous editions, does not damage their value, or that of their author, let alone their contents, for not "all that glitters is gold", maybe just gilded. Modern man has to choose between the "fashion" of the present times, according to which civil laws are changed almost every month, because they are not good, since they are conceived according to the interests of the present moment, having an immediate purpose (The "fast food law" or that of "single-use items"), and the law of the Church (the canon, guide-lines, norms and decisions), that crossed the times and proved to be the treasurer of the truth. The fact that the above mentioned issues are true may be

${ }^{25}$ Canon 33, local synod VIII, Carthage, Nicodim Milaş, Canoanele Bisericii Ortodoxe ..., vol. II, part. I, p. 191. 
proved not only by the wise saying that "he, who has no elder people around him, should get himself some", but also by the following dilemma concerning the administration of the goods. For 25 years, the legislative power has been looking inside the present Romanian civil legislation for a solution to the problem of the unproper administration of the goods by its upper representatives, and the problem has not been solved yet. However, the Church had already solved it in the year 419, when it disposed: "It also seemed good that bishops, presbyters, deacons and any other of the clergy who when they were ordained had no possessions, and in the time of their episcopate or after they became clerics, shall purchase in their own names land or any other property, shall be held guilty of the crime of entrenching upon the Lord's good, unless, when they are admonished to do so, to place the same at the disposal of the Church. But should anything come to them personally by the liberality of anyone or by succession from some relatives, let them do what they will with it; if, however, they demanded back again, contrary to what they proposed, they shall be judged unworthy of ecclesiastical honor as backsliders" 26 .

${ }^{26}$ Canon 32, local synod VIII, Carthage, Ioan N. Floca, Canoanele Bisericii Ortodoxe - note şi comentarii, Sibiu, 2005, p. 282. 